\title{
PENERAPAN PEMBELAJARAN TGT DENGAN RODA PUTAR UNTUK MENINGKATKAN AKTIVITAS BELAJAR AKUNTANSI SISWA SMKN 1 TEMPEL
}

\section{THE IMPLEMENTATION OF TGT LEARNING WITH ROTARY WHELLS TO IMPROVE STUDENT'S ACCOUNTING LEARNING ACTIVITY AT SMK NEGERI 1 TEMPEL}

\author{
Oleh: \\ Noni Istifar Rina \\ Prodi Pendidikan Akuntansi Universitas negeri Yogyakarta \\ noniistifarr@yahoo.com \\ Sukanti \\ Staf Pengajar Jurusan P. Akuntansi Universitas Negeri Yogyakarta
}

\begin{abstract}
Abstrak
Penelitian Tindakan Kelas ini bertujuan untuk meningkatkan Aktivitas Belajar Akuntansi Siswa Kelas XI Akuntansi 1 SMK Negeri 1 Tempel Tahun Ajaran 2015/2016 melalui Penerapan Model Pembelajaran Kooperatif Tipe Teams Games Tournament (TGT) Berbantu Media Roda Putar. Subjek dalam penelitian ini adalah Siswa Kelas XI Akuntansi 1 SMK Negeri 1 Tempel Tahun Ajaran 2015/2016 yang berjumlah 32 siswa. Instrumen data yang digunakan yaitu lembar observasi dan catatan harian guru. Analisis data yang digunakan adalah data deskriptif dalam bentuk persentase. Hasil penelitian ini menunjukkan bahwa Penerapan Model Pembelajaran Kooperatif Tipe Teams Games Tournament (TGT) Berbantu Media Roda Putar dapat Meningkatkan Aktivitas Belajar Akuntansi Siswa Kelas XI Akuntansi 1 SMK Negeri 1 Tempel Tahun Ajaran 2015/2016. Dibuktikan dengan adanya peningkatan setiap indikator Aktivitas Belajar Akuntansi dari sikus I ke siklus II. Peningkatan skor rata-rata aktivitas belajar akuntansi sebesar 26,37\% (relatif) dan 18,75\% (absolut) dari siklus I sebesar $71,09 \%$ menjadi sebesar $89,84 \%$ pada siklus II.
\end{abstract}

Kata Kunci: Pembelajaran Kooperatif tipe Teams Games Tournament (TGT), Media Roda Putar Akuntansi, Aktivitas Belajar Akuntansi Siswa, SMK Negeri 1 Tempel

\section{Abstract}

Classroom action research which aims to improve student's accounting learning activity in class XI accounting 1 at SMK Negeri 1 Tempel academic year of 2015/2016 through the implementation of cooperative learning model type teams games tournament assisted rotary wheels. The subject of this research is the students of class XI accounting 1 at SMK Negeri 1 Tempel academic year of 2015/2016 some thirty two's student. The data instrument was used observations sheet and teachers daily note. Data analysis is a data deskripstif type percentages. The results showed that the implementation of cooperative learning model type teams games tournament rotary wheels assisted media can improve student's accounting learning activity of students in class XI accounting 1 at State SMK Negeri 1 Tempel academic year of 2015/2016. Evidenced by an increase in each indicator being accounting learning activity from cycle I to cycle II. Increased in the average score of accounting learning activity at the amount of $26,37 \%$ (relative) and $18,75 \%$ (absolute) from cycle I at the amount $71,09 \%$ increase to be $89,84 \%$ in cycle II.

Keywords: Cooperative Learning Type Teams Games Tournament (TGT), Rotary Wheels Media, Students accounting learning activity, SMK Negeri 1 Tempel 


\section{PENDAHULUAN}

Pendidikan memiliki peran yang sangat penting bagi kehidupan masyarakat karena merupakan salah satu faktor yang sangat fundamental dalam meningkatkan kualitas kehidupan dan mengangkat harkat serta martabat suatu bangsa. Pemerintah dewasa ini sangat memperhatikan segala aspek pendidikan yang ada untuk memperbaiki dan meningkatkan kualitas pendidikan nasional. Undang-Undang No.20 tahun 2003 tentang Sistem Pendidikan Nasional Pasal 3 menyatakan bahwa: Pendidikan nasional berfungsi mengembangkan kemampuan dan membentuk watak serta peradaban bangsa yang bermanfaat dalam rangka mencerdaskan kehidupan bangsa, bertujuan untuk berkembangnya potensi peserta didik agar menjadi manusia yang beriman dan bertakwa kepada Tuhan Yang Maha Esa, berakhlak mulia, sehat, berilmu, cakap, kreatif, mandiri, dan menjadi warga negara yang demokratis secara bertanggung jawab. Tujuan pendidikan nasional tersebut akan tercapai jika proses pembelajaran dapat berjalan dengan baik. Tujuan pendidikan nasional tercapai jika proses pembelajaran berjalan dengan baik karena upaya peningkatan kualitas pendidikan tidak terlepas dari keberhasilan akan proses pembelajaran.

Salah satu masalah yang dihadapi dunia pendidikan di Indonesia adalah lemahnya proses pembelajaran yang dikembangkan oleh guru karena siswa kurang didorong untuk aktif. Proses pembelajaran didalam kelas hanya diarahkan kepada kemampuan siswa untuk menghafal pelajaran dan guru hanya menggunakan komunikasi satu arah sehingga tidak berusaha mengajak siswa untuk berpikir. Guru pada umumnya hanya mengajar dengan model ceramah dan latihan saja. Jika kondisi tersebut terus terjadi, dikhawatirkan akan menurunkan keberhasilan proses pembelajaran. Pada dasarnya, proses pembelajaran harus diarahkan agar siswa mampu mengatasi setiap tantangan dan rintangan dalam kehidupan yang berubah dengan cepat melalui sejumlah kompetensi yang dimiliki, yang meliputi kompetensi akademik, kompetensi okupasional, kompetensi kultural, dan kompetensi temporal (Wina Sanjaya, 2014: 106). John Dewey mengemukakan bahwa belajar harus bersifat aktif, langsung terlibat, dan berpusat pada siswa dalam konteks pengalaman sosial (Sugihartono dkk, 2012; 108). Dengan cara ini, siswa merasakan suasana yang lebih menyenangkan dalam belajar sehingga aktivitas belajar dapat dimaksimalkan dan tidak cepat melupakan apa yang telah diberikan. Untuk itu, guru dituntut untuk kreatif dan inovatif sehingga mampu menyesuaikan kegiatan mengajarnya dengan gaya dan karakteristik belajar siswa. Menurut Sugihartono dkk (2012: 76), belajar dipengaruhi oleh dua faktor yaitu faktor internal dan faktor eksternal. Faktor internal adalah faktor yang ada dalam diri individu yang sedang belajar, sedangkan faktor eksternal adalah faktor yang berada di luar diri individu.

Model pembelajaran merupakan salah satu faktor eksternal yang menentukan keberhasilan dalam belajar. Salah satu model pembelajaran yaitu model pembelajaran kooperatif tipe Teams Games Tournament (TGT), yaitu pembelajaran kooperatif yang melibatkan aktivitas seluruh siswa, melibatkan belajar kelompok, dan mengandung unsur permainan serta reinforcement. Menurut Wina Sanjaya (2014: 241), model pembelajaran kooperatif adalah rangkaian kegiatan yang dilakukan oleh siswa-siswa dalam kelompok-kelompok tertentu untuk mencapai tujuan pembelajaran yang telah dirumuskan. Dengan adanya aktivitas-aktivitas dalam kelompok tersebut, maka siswa akan lebih aktif dalam belajar karena antar anggota kelompok saling membelajarkan baik melalui bertukar pikiran, pengalaman, maupun gagasangagasan. Aktivitas belajar dengan permainan yang dirancang dalam pembelajaran kooperatif tipe TGT memungkinkan siswa dapat belajar lebih rileks disamping 
menumbuhkan tanggung jawab, kerjasama, persaingan sehat dan keterlibatan belajar.

Agar materi yang disampaikan oleh guru dapat diterima dengan baik oleh siswa, maka dibutuhkan bantuan suatu media. Peran media pengajaran merupakan perantara untuk memudahkan proses belajarmengajar agar tercapai tujuan pengajaran secara efektif dan efisien (Zainal Arifin dan Adhi Setiyawan, 2012: 125). Salah satu media yang digunakan dalam pembelajaran Akuntansi adalah media permainan. Permainan memberikan lingkungan kompetitif yang biasanya menjadikan siswa termotivasi melakukannya, apalagi dengan adanya permainan bersifat kompetitif, semua siswa akan lebih aktif karena mereka mencoba untuk menjadi pemenang. Sebagai salah satu bentuk variasi media pembelajaran akuntansi adalah media roda putar Akuntansi. Roda Putar Akuntansi (ROTASI) adalah suatu alat yang berbentuk lingkaran dan bergambar yang dapat diputar pada porosnya hingga pada akhirnya akan berhenti di salah satu bagian gambar yang dapat digunakan sebagai media pembelajaran Akuntansi.

Berdasarkan observasi awal yang dilakukan pada tanggal 28 September 2015 di SMK Negeri 1 Tempel, diketahui bahwa diantara 3 kelas XI Akuntansi, kelas XI Akuntansi 1 memiliki masalah yaitu Aktivitas Belajar Akuntansi yang masih rendah kurang dari $75 \%$. Aktivitas belajar yang rendah tersebut dapat dilihat ketika pembelajaran berlangsung yaitu siswa hanya duduk, memperhatikan dan mendengarkan. Siswa dalam proses pembelajaran bertindak sebagai objek pembelajaran. Kurangnya aktivitas bertanya maupun berpendapat membuat pembelajaran menjadi monoton. Model pembelajaran yang diterapkan guru kurang bervariasi sehingga terkadang pun siswa bosan dan lebih senang melakukan aktivitas lain, seperti diskusi sendiri dengan teman lainnya, dan tidak memperhatikan saat guru menerangkan materi. Hal tersebut dapat disebabkan salah satunya karena model pembelajaran yang digunakan oleh guru membosankan yaitu hanya ceramah saja. Padahal, penggunaan model pembelajaran yang tidak sesuai dengan minat siswa akan menyebabkan siswa tidak memperhatikan guru yang sedang menerangkan materi pelajaran. Hal tersebut menyebabkan aktivitas siswa berkurang. Ada 11 dari 32 siswa atau sekitar 34\% siswa yang lebih suka berbicara dengan temannya daripada memperhatikan penjelasan materi dari guru, hanya 5 dari 32 siswa atau sekitar $15 \%$ siswa yang bertanya saat guru memberikan kesempatan untuk bertanya, dan 10 siswa atau sekitar $31 \%$ siswa yang tidak mencatat materi yang dijelaskan oleh guru. Selain itu, peneliti juga mewawancarai guru pengampu mata pelajaran akuntansi dan menyatakan bahwa kelas XI Akuntansi 1 aktivitas belajarnya masih kurang. Guru menyatakan belum pernah menerapkan pembelajaran kooperatif tipe TGT dengan bantuan suatu media karena guru tidak memiliki pengalaman dengan penerapan media dan keterbatasan waktu yang dimiliki guru untuk menyiapkan pembelajaran dengan metode pembelajaran yang menarik sedangkan guru dituntut untuk cepat dalam menyelesaikan target materi yang ada di sekolah.

Dari uraian di atas, dapat disimpulkan bahwa monotonnya model pembelajaran yang digunakan oleh guru saat mengajar dapat menimbulkan rendahnya Aktivitas Belajar Siswa karena siswa di dalam kelas hanya mendengarkan penjelasan dari gurunya melalui ceramah dan mengerjakan latihan soal. Jika hal tersebut terus terjadi, dikhawatirkan akan menurunkan keberhasilan proses pembelajaran. Untuk itu, perlu dilakukan upaya untuk mendorong aktivitas siswa agar mau belajar, sehingga peneliti mencoba untuk melakukan penelitian dengan Judul "Penerapan Model Pembelajaran Kooperatif Tipe Teams Games Tournament (TGT) Dengan Media Roda Putar Untuk Meningkatkan Aktivitas Belajar Akuntansi Siswa Kelas XI Akuntansi 1 SMK Negeri 1 Tempel Tahun Ajaran 2015/2016". 


\section{METODE PENELITIAN Jenis Penelitian}

Penelitian ini merupakan penelitian tindakan kelas (Classroom Action Research) yang bersifat kolaboratif dan partisipatif antara peneliti dan guru, khususnya guru Kompetensi Dasar Membukukan Mutasi Piutang ke Kartu Piutang SMK Negeri 1 Tempel.

\section{Waktu dan Tempat Penelitian}

Penelitian ini dilakukan di Sekolah Menengah Kejuruan (SMK) Negeri 1 Tempel yang beralamat di Jalan Magelang Km.17 Sleman khususnya di kelas XI Akuntansi 1. Penelitian ini dilaksanakan pada bulan September sampai bulan Desember 2015.

\section{Target/Subjek Penelitian}

Subjek penelitian ini adalah seluruh siswa kelas XI Akuntansi 1 SMK Negeri 1 Tempel Tahun Ajaran 2015/2016 yang berjumlah 32 siswa.

\section{Prosedur Penelitian}

Penelitian ini dilaksanakan dalam dua siklus yang meliputi:

a. Siklus I

1) Perencanaan (Planning)

Pada tahap perencanaan, peneliti menyiapkan segala sesuatu yang dibutuhkan saat pelaksanaan, seperti:

a) Membuat RPP

b) Menyiapkan materi

c) Menyiapkan dan membuat media pembelajaran Roda Putar Akuntansi (ROTASI).

d) Membuat kelompok belajar siswa secara heterogen sebanyak 8 kelompok, dimana satu kelompok terdiri atas 4 siswa.

e) Membuat latihan soal untuk dibahas dalam belajar kelompok.

f) Membuat pengelompokan siswa secara homogen sebanyak 8 kelompok yang terdiri dari perwakilan masing-masing kelompok secara heterogen untuk menempatkan diri pada meja turnamen.

g) Membuat ketentuan game.

h) Membuat form penilaian game.

i) Membuat lembar observasi.

j) Membuat format catatan harian.

k) Konsultasi kepada guru mata pelajaran.

1) Mempersiapkan reward.

2) Pelaksanaan Tindakan (Acting)

a) Tahap Mengajar

Tindakan diawali dengan penjelasan materi pelajaran yang disampaikan oleh guru kelas dan materi yang dijelaskan yaitu Pencatatan Piutang Berbagai Metode dan Penagihan Piutang akan menjadi bahasan dalam pembelajaran kooperatif tipe teams games tournament.

b) Belajar Tim

Guru membagi siswa ke dalam 8 kelompok yang terdiri dari 4 siswa dengan kemampuan akademik yang berbeda yang bertujuan agar siswa saling membelajarkan antarsiswa dan diharapkan tiap kelompok dapat berusaha untuk memenangkan tournament.

c) Games Tournament

Masing-masing siswa mewakili kelompoknya di setiap meja turnamen untuk mendapatkan skor agar kelompoknya memenangkan game.

3) Pengamatan

Peneliti bersama dua orang observer mengamati proses pembelajaran dengan berpedoman pada lembar observasi aktivitas siswa yang telah dipersiapkan agar data yang diperoleh lebih akurat untuk perbaikan pada siklus berikutnya. 
4) Refleksi

Tahap refleksi merupakan kegiatan yang dilakukan untuk mengetahui kelebihan dan kekurangan proses pembelajaran yang telah dilakukan. Guru bersama peneliti dapat mencari solusi terhadap masalah-masalah yang mungkin timbul pada siklus II agar dapat dibuat rencana perbaikan dari siklus I.

b. Siklus II

Adapun kegiatan yang dilakukan pada siklus II ini pada intinya sama dengan kegiatan yang dilakukan pada siklus I, namun kegiatan yang dilakukan di siklus II ini mengacu atau berpedoman pada refleksi pada siklus I dengan tujuan agar peneliti dapat memperbaiki tindakan dan pelaksanaan pembelajaran di siklus II, serta indikator keberhasilan yang diharapkan akan tercapai.

\section{Data, Instrumen, dan Teknik Pengumpulan}

a) Data

Dalam penelitian ini, pengumpulan data dilakukan dengan menggunakan.

1) Observasi Partisipatif

Observasi partisipatif adalah observasi yang dilakukan apabila observer ikut serta dalam kegiatan atau situasi yang dilakukan oleh observant (Wina Sanjaya, 2012: 92). Keuntungan yang diperoleh dari observasi partisipatif ini yaitu observant akan bertingkah laku secara wajar dan tidak dibuat-buat karena mereka tidak merasa sedang diamati karena observer ikut ambil bagian secara bersama-sama.
2) Dokumentasi

Dokumen yang digunakan dalam penelitian ini adalah catatan harian. Catatan harian merupakan instrumen untuk mencatat segala peristiwa yang terjadi sehubungan dengan tindakan yang diberikan guru (Wina Sanjaya, 2012: 98). Kekayaan data dalam catatan harian ini, yang memuat secara deskriptif berbagai kegiatan, suasana kelas, iklim sekolah, kepemimpinan, berbagi bentuk interaksi sosial, dan nuansa lainnya (Rochiati Wiraatmadja, 2012: 125).

b) Instrumen Penelitian

1) Lembar Observasi

Pedoman observasi mengenai Aktivitas Belajar Akuntansi berisi pedoman pengamatan terhadap aktivitas yang terjadi selama proses pembelajaran di kelas. Adapun indikator Aktivitas Belajar Akuntansi Siswa yang akan diteliti yaitu:

Tabel 1. Indikator Aktivitas Belajar Akuntansi yang Akan Diamati

\begin{tabular}{|c|c|l|}
\hline Aspek & $\begin{array}{c}\text { Indi- } \\
\text { kator }\end{array}$ & \multicolumn{2}{|c|}{ Uraian Indikator } \\
\hline $\begin{array}{c}\text { Visual } \\
\text { Activiti } \\
\text { es }\end{array}$ & $\mathrm{a}$ & $\begin{array}{l}\text { Siswa memperhatikan } \\
\text { penjelasan dari guru saat } \\
\text { presentasi materi } \\
\text { pembelajaran }\end{array}$ \\
\cline { 2 - 4 } & $\mathrm{b}$ & $\begin{array}{l}\text { Siswa membaca materi } \\
\text { pembelajaran Akuntansi }\end{array}$ \\
\hline $\begin{array}{c}\text { Oral } \\
\text { Activiti }\end{array}$ & $\mathrm{c}$ & $\begin{array}{l}\text { Siswa berdiskusi dengan } \\
\text { teman saat belajar kelompok }\end{array}$ \\
\cline { 2 - 4 } & $\mathrm{d}$ & $\begin{array}{l}\text { Siswa bertanya kepada guru } \\
\text { pada saat presentasi materi } \\
\text { pembelajaran/saat kegiatan } \\
\text { belajar kelompok. }\end{array}$ \\
\cline { 2 - 4 } & $\mathrm{e}$ & $\begin{array}{l}\text { Siswa memberi jawaban, } \\
\text { saran, pendapat, ataupun } \\
\text { komentar kepada guru/teman } \\
\text { tentang materi yang telah } \\
\text { dibahas. }\end{array}$ \\
\hline
\end{tabular}




\begin{tabular}{|c|c|l|}
\hline Aspek & $\begin{array}{c}\text { Indi- } \\
\text { kator }\end{array}$ & \multicolumn{1}{|c|}{ Uraian Indikator } \\
\hline $\begin{array}{c}\text { Lisan } \\
\text { Activities }\end{array}$ & $\mathrm{f}$ & $\begin{array}{l}\text { Siswa mendengarkan } \\
\text { penjelasan guru pada } \\
\text { saat kegiatan presentasi } \\
\text { materi pembelajaran }\end{array}$ \\
\cline { 2 - 4 } & $\mathrm{g}$ & $\begin{array}{l}\text { Siswa mendengarkan } \\
\text { penjelasan teman pada } \\
\text { saat kegiatan belajar } \\
\text { kelompok/saat game } \\
\text { tournament Roda Putar } \\
\text { Akuntansi. }\end{array}$ \\
\hline Writing & $\mathrm{h}$ & $\begin{array}{l}\text { Siswa mencatat materi } \\
\text { yang disampaikan oleh } \\
\text { guru saat presentasi } \\
\text { materi pembelajaran }\end{array}$ \\
${$\cline { 2 - 4 }$} }$ & $\mathrm{i}$ & $\begin{array}{l}\text { Siswa mengerjakan } \\
\text { latihan yang diberikan } \\
\text { guru dalam kegiatan } \\
\text { belajar kelompok. }\end{array}$ \\
\hline Mental & $\mathrm{j}$ & $\begin{array}{l}\text { Siswa memecahkan } \\
\text { soal saat game } \\
\text { tournament dengan } \\
\text { media Roda Putar } \\
\text { Akuntansi. }\end{array}$ \\
\hline
\end{tabular}

(dalam Sardiman A.M., 2011: 101)

Pedoman penskoran Aktivitas Belajar Akuntansi dengan Model Pembelajaraan Kooperatif Tipe TGT yaitu sebagai berikut:

Tabel 2. Pedoman Penskoran Aktivitas Belajar Akuntansi

\begin{tabular}{|l|l|}
\hline \multicolumn{1}{|c|}{$\begin{array}{c}\text { Kategori setiap } \\
\text { indikator }\end{array}$} & $\begin{array}{c}\text { Skor } \\
\text { Penilaian }\end{array}$ \\
\hline Aktif & 2 \\
\hline Cukup Aktif & 1 \\
\hline Tidak Aktif & 0 \\
\hline
\end{tabular}

2) Catatan Harian (Dokumentasi)

Dokumentasi dalam penelitian yaitu berupa catatan harian guru yang berisi kesan dan penafsiran guru dalam bentuk naratif-deskriptif yang menje;askan kapan waktu pembelajaran dimulai dan diakhiri, berapa jumlah siswa yang hadir sampai jam pelajaran akuntansi selesai, gambaran ekspresi siswa, suasana kelas dan prosedur yang dilaksanakan dalam menerapkan pembelajaran koopetatif tipe TGT berbantu media roda putar akuntansi.

c) Teknik Analisis Data

Teknik analisis data yang digunakan yaitu Analisis Data Deskriptif Kuantitatif dengan Persentase. Analisis ini dilakukan dengan:

1) Mengolah skor Aktivitas Belajar Akuntansi

a) Membuat kategori penyekoran untuk Aktivitas Belajar Akuntansi

b) Menghitung dan menjumlahkan skor untuk masing-masing Aktivitas Belajar Akuntansi yang diamati.

c) Menghitung skor Aktivitas Belajar Akuntansi pada setiap aspek yang diamati dengan rumus: jumlah skor pada setiap aspek $x 100 \%$ skor maksimum

(Sugiyono, 2013: 143)

d) Menghitung peningkatan persentase skor siklus Aktivitas Belajar Akuntansi tiap indikator dengan rumus:

(1) Peningkatan persentase relatif skor siklus tiap indikator dengan rumus:

$$
\frac{B-A}{A} \times 100 \%
$$

Keterangan:

B : Persentase Skor Siklus II tiap indikator

A : Persentase Skor Siklus I tiap indikator

(2) Peningkatan persentase absolut skor siklus tiap indikator dengan rumus:

$$
B-A
$$

Keterangan:

B : Persentase Skor Siklus II tiap indikator

A : Persentase Skor Siklus I tiap indikator 
2) Menghitung persentase skor rata-rata Aktivitas Belajar Akuntansi dengan rumus: $\frac{\text { Shor Total Aktivitas Belajar }}{\text { Jumiah indikator }} \times 100 \%$

3) Menyajikan Data

Setelah data mengenai Aktivitas Belajar Akuntansi diolah, data disampaikan secara sederhana dan disajikan dalam bentuk tabel dan grafik sehingga mudah dipahami.

4) Menarik Kesimpulan

Setelah data disajikan dalam bentuk tabel dan grafik, kemudian dilakukan pemaknaan data ke dalam pernyataan.

\section{HASIL PENELITIAN DAN PEMBA- HASAN \\ Siklus I}

Siklus I dilaksanakan dalam 1 kali pertemuan (@3 x 45 menit). Hal tersebut dikarenakan pertimbangan guru yang beranggapan bahwa 1 kali pertemuan sudah cukup, dan apabila penerapan model TGT ini dilakukan lebih dari satu pertemuan maka siswa mudah merasa jenuh dan bosan.

Tindakan pada Siklus I ini dilaksanakan pada hari Kamis, 15 Oktober 2015 pukul 07.00-09.30 WIB. Adapun materi yang dipelajari pada pertemuan ini adalah Pencatatan Piutang Berbagai Metode dan Penagihan Piutang. Peneliti dibantu oleh dua orang observer dalam mengamati Aktivitas Belajar Akuntansi. Adapun hasil dari penelitiannya yaitu:

\section{Tabel 2. Hasil Observasi Aktivitas Belajar Akuntansi Siswa pada Siklus I}

\begin{tabular}{|c|c|c|}
\hline \multirow{2}{*}{ Aspek } & Indikator & $\begin{array}{c}\text { \% Aktivitas } \\
\text { per } \\
\text { Indikator }\end{array}$ \\
\hline \multirow{2}{*}{$\begin{array}{c}\text { Visual } \\
\text { Activities }\end{array}$} & $\mathrm{a}$ & $82,81 \%$ \\
\hline $\begin{array}{c}\text { Oral } \\
\text { Activities }\end{array}$ & $\mathrm{b}$ & $76,56 \%$ \\
\cline { 2 - 3 } & $\mathrm{d}$ & $89,06 \%$ \\
\hline & $\mathrm{e}$ & $75,94 \%$ \\
\hline $\begin{array}{c}\text { Lisan } \\
\text { Activities }\end{array}$ & $\mathrm{f}$ & $81,25 \%$ \\
\hline $\begin{array}{c}\text { Writing } \\
\text { Activities }\end{array}$ & $\mathrm{g}$ & $84,38 \%$ \\
\hline Mental & $\mathrm{i}$ & $43,75 \%$ \\
Activities & $\mathrm{j}$ & $68,75 \%$ \\
\hline $\begin{array}{c}\text { Skor Rata-Rata Aktivitas } \\
\text { Belajar Akuntansi Siswa } \\
\text { Silus I }\end{array}$ & $78,13 \%$ \\
\hline \multicolumn{2}{|c|}{$71,09 \%$} \\
\hline
\end{tabular}

(sumber : data primer yang diolah)

Skor total rata-rata Aktivitas Belajar Akuntansi Siswa pada Siklus I diatas yaitu hanya mencapai $71,09 \%$, sehingga belum dapat dikatakan berhasil. Perlu dilakukan refleksi terhadap hasil Siklus I untuk perbaikan di Siklus II.

\section{Siklus II}

Siklus II dilaksanakan dalam 1 kali pertemuan saja (@ 3 x 45 menit) dikarenakan pertimbangan guru yang beranggapan bahwa 1 kali pertemuan sudah cukup, mengingat masih banyak materi lain yang harus dipelajari siswa dan dikhawatirkan siswa mudah jenuh dan bosan.

Tindakan pada siklus II ini dilaksanakan pada hari Kamis, 22 Oktober 2015 pukul 07.00-09.30 WIB. Adapun materi yang dipelajari pada pertemuan ini adalah Penghapusan Piutang. Peneliti dibantu oleh satu orang observer dalam mengamati Aktivitas Belajar Akuntansi. Adapun hasil dari penelitiannya yaitu: 
Tabel 3. Hasil Observasi Aktivitas Belajar Akuntansi Siswa Pada Siklus II

\begin{tabular}{|c|c|c|}
\hline Aspek & Indikator & $\begin{array}{c}\% \text { Aktivitas } \\
\text { per Indikator }\end{array}$ \\
\hline \multirow{2}{*}{$\begin{array}{c}\text { Visual } \\
\text { Activities }\end{array}$} & $\mathrm{a}$ & $88,71 \%$ \\
\hline & $\mathrm{b}$ & $91,94 \%$ \\
\hline \multirow{3}{*}{$\begin{array}{c}\text { Oral } \\
\text { Activities }\end{array}$} & $\mathrm{c}$ & $91,94 \%$ \\
\hline & $\mathrm{d}$ & $75,81 \%$ \\
\hline & $\mathrm{e}$ & $83,87 \%$ \\
\hline \multirow{2}{*}{$\begin{array}{c}\text { Lisan } \\
\text { Activities }\end{array}$} & $\mathrm{f}$ & $87,10 \%$ \\
\hline & $\mathrm{g}$ & $90,32 \%$ \\
\hline \multirow{2}{*}{$\begin{array}{c}\text { Writing } \\
\text { Activities }\end{array}$} & $\mathrm{h}$ & $100 \%$ \\
\hline & $\mathrm{i}$ & $100 \%$ \\
\hline $\begin{array}{c}\text { Mental } \\
\text { Activities }\end{array}$ & $\mathrm{j}$ & $88,71 \%$ \\
\hline \multicolumn{2}{|c|}{$\begin{array}{l}\text { Skor Rata-Rata } \\
\text { Aktivitas Belajar } \\
\text { Akuntansi Siswa Silus II }\end{array}$} & $89,84 \%$ \\
\hline
\end{tabular}

(sumber: data primer yang diolah)

Tabel tersebut menunjukkan bahwa ratarata Aktivitas Belajar Siswa pada Siklus II sebesar 89,84\%. Hal tersebut menunjukkan rata-rata Aktivitas Belajar Akuntansi Siswa sudah mencapai kriteria minimal, yaitu sebesar $75 \%$.

\section{Pembahasan}

Pelaksanaan penelitian tindakan kelas ini dilakukan sebanyak dua siklus dengan tujuan untuk meningkatkan Aktivitas Belajar Akuntansi Siswa Kelas XI Akuntansi 1 SMK Negeri 1 Tempel Tahun Ajaran 2015/2016 melalui penerapan Model Pembelajaran Kooperatif Tipe Teams Games Tournament (TGT) Berbantu Media Roda Putar Akuntansi. Penelitian ini dilatarbelakangi oleh masih rendahnya Aktivitas Belajar Akuntansi Siswa Kelas XI Akuntansi 1 SMK Negeri 1 Tempel Tahun Ajaran 2015/2016.

Adapun tahapan dalam pelaksanaan di setiap siklusnya meliputi kegiatan presentasi kelompok, belajar kelompok, games tournament, dan penghargaan kelompok.Pada siklus I, secara keseluruhan proses pembelajaran berjalan dengan baik namun terdapat beberapa kendala seperti manajemen waktu, belum terbiasanya siswa dalam menerapkan Model Pembelajaran Kooperatif Tipe Teams Games Tournament (TGT) Berbantu Media Roda Putar Akuntansi sehingga masih terdapat kebingungan, siswa masih belum banyak yang bertanya kepada guru/teman, dan hanya beberapa siswa yang mencatat materi pembelajaran. Hal tersebut menyebabkan persentase Aktivitas Belajar Akuntansi Siswa pada siklus I belum mencapai indikator keberhasilan yaitu hanya mencapai persentase sebesar $71,09 \%$ sehingga perlu dilanjutkan tindakan pada siklus II.

Pada siklus II, pelaksanaan pembelajaran melihat dari hasil refleksi siklus I dengan tujuan untuk memperbaiki kekurangan pada siklus I sehingga tujuan yang telah ditetapkan dapat tercapai. Penerapkan Model Pembelajaran Kooperatif Tipe Teams Games Tournament (TGT) Berbantu Media Roda Putar Akuntansi pada siklus II ini sudah berjalan dengan baik dan kendala-kendala yang ada pada siklus I sudah diperbaiki. Pada siklus II terjadi peningkatan Aktivitas Belajar Akuntansi Siswa dibandingkan siklus I. Hal tersebut menunjukkan bahwa tindakan yang dilakukan berpengaruh terhadap Aktivitas Belajar Akuntansi siswa yang meningkat mencapai skor minimal yang telah ditentukan.

Adapun persentase tiap indikator yang masih kurang pada siklus I dan sudah meningkat pada siklus II yaitu aktivitas siswa bertanya kepada guru pada saat presentasi materi pembelajaran/saat kegiatan belajar kelompok meningkat persentasenya menjadi $75,81 \%$, siswa memberi jawaban, saran, pendapat, ataupun komentar kepada guru/teman tentang materi yang telah dibahas meningkat persentasenya menjadi $83,87 \%$, siswa mencatat materi yang disampaikan oleh guru saat presentasi materi pembelajaran meningkat persentasenya 
menjadi $100 \%$, dan siswa mengerjakan latihan yang diberikan guru dalam kegiatan belajar kelompok meningkat persentasenya menjadi $100 \%$. Untuk lebih jelasnya, berikut ini disajikan data Aktivitas Belajar Akuntansi siswa pada tindakan siklus I dan siklus II:

Berikut ini disajikan data Aktivitas Belajar Akuntansi siswa pada tindakan siklus I dan siklus II:

Tabel 4. Hasil Observasi Aktivitas Belajar Akuntansi Siswa pada Siklus I dan Siklus II

\begin{tabular}{|c|c|c|c|c|}
\hline \multirow{2}{*}{$\begin{array}{c}\text { Indika } \\
\text { tor }\end{array}$} & \multicolumn{2}{|c|}{ \% Aktivitas } & \multicolumn{2}{|c|}{$\begin{array}{c}\text { Peningkatan } \\
\%\end{array}$} \\
\hline & $\begin{array}{c}\text { Siklus } \\
\text { I }\end{array}$ & $\begin{array}{c}\text { Siklus } \\
\text { II }\end{array}$ & $\begin{array}{c}\text { Absol } \\
\text { ut }\end{array}$ & $\begin{array}{l}\text { Relat } \\
\text { if }\end{array}$ \\
\hline $\mathrm{a}$ & $\begin{array}{c}82,81 \\
\%\end{array}$ & $\begin{array}{c}88,71 \\
\%\end{array}$ & $5,90 \%$ & $\begin{array}{c}7,12 \\
\%\end{array}$ \\
\hline $\mathrm{b}$ & $\begin{array}{c}76,56 \\
\%\end{array}$ & $\begin{array}{c}91,94 \\
\% \\
\end{array}$ & $\begin{array}{c}15,38 \\
\%\end{array}$ & $\begin{array}{c}20,08 \\
\%\end{array}$ \\
\hline $\mathrm{c}$ & $\begin{array}{c}89,06 \\
\%\end{array}$ & $\begin{array}{c}91,94 \\
\%\end{array}$ & $2,88 \%$ & $\begin{array}{c}3,23 \\
\%\end{array}$ \\
\hline $\mathrm{d}$ & $\begin{array}{c}35,94 \\
\%\end{array}$ & $\begin{array}{c}75,81 \\
\%\end{array}$ & $\begin{array}{c}39,87 \\
\%\end{array}$ & $\begin{array}{c}110,9 \\
5 \%\end{array}$ \\
\hline $\mathrm{e}$ & $\begin{array}{c}70,31 \\
\%\end{array}$ & $\begin{array}{c}83,87 \\
\%\end{array}$ & $\begin{array}{c}13,56 \\
\%\end{array}$ & $\begin{array}{c}19,28 \\
\%\end{array}$ \\
\hline $\mathrm{f}$ & $\begin{array}{c}81,25 \\
\%\end{array}$ & $\begin{array}{c}87,10 \\
\%\end{array}$ & $5,85 \%$ & $\begin{array}{c}7,20 \\
\%\end{array}$ \\
\hline g & $\begin{array}{c}84,38 \\
\%\end{array}$ & $\begin{array}{c}90,32 \\
\%\end{array}$ & $5,94 \%$ & $\begin{array}{c}7,05 \\
\%\end{array}$ \\
\hline $\mathrm{h}$ & $\begin{array}{c}43,75 \\
\%\end{array}$ & $100 \%$ & $\begin{array}{c}56,25 \\
\%\end{array}$ & $\begin{array}{c}128,5 \\
7 \%\end{array}$ \\
\hline $\mathrm{i}$ & $\begin{array}{c}68,75 \\
\%\end{array}$ & $100 \%$ & $\begin{array}{c}31,25 \\
\%\end{array}$ & $\begin{array}{c}45,45 \\
\%\end{array}$ \\
\hline $\mathrm{j}$ & $\begin{array}{c}78,13 \\
\%\end{array}$ & $\begin{array}{c}88,71 \\
\%\end{array}$ & $\begin{array}{c}10,58 \\
\%\end{array}$ & $\begin{array}{c}13,55 \\
\%\end{array}$ \\
\hline $\begin{array}{l}\text { Skor } \\
\text { rata- } \\
\text { rata } \\
\text { Aktivit } \\
\text { as } \\
\text { Belajar } \\
\text { Akunta } \\
\text { nsi }\end{array}$ & $\begin{array}{c}71,09 \\
\%\end{array}$ & $\begin{array}{c}89,84 \\
\%\end{array}$ & $\begin{array}{c}18,75 \\
\%\end{array}$ & $\begin{array}{c}26,37 \\
\%\end{array}$ \\
\hline
\end{tabular}

Keterangan:

a : Siswa memperhatikan penjelasan dari guru saat presentasi materi pembelajaran

b : Siswa membaca materi pembelajaran Akuntansi

$\mathrm{c}$ : Siswa berdiskusi dengan teman $\mathrm{n}$ saat belajar kelompok

$\mathrm{d}$ : Siswa bertanya kepada guru/teman pada saat presentasi materi pembelajaran/saat kegiatan belajar kelompok

e : Siswa memberi jawaban, saran, pendapat, ataupun komentar kepada guru/teman tentang materi yang telah dibahas

$\mathrm{f}$ : Siswa mendengarkan penjelasan guru pada saat kegiatan presentasi materi pembelajaran

$\mathrm{g}$ : Siswa mendengarkan penjelasan teman pada saat kegiatan belajar kelompok/saat game tournament Roda Putar Akuntansi

$\mathrm{h}$ : Siswa mencatat materi yang disampaikan oleh guru saat presentasi materi pembelajaran

i : Siswa mengerjakan latihan yang diberikan guru dalam kegiatan belajar kelompok

$\mathrm{j}$ : Siswa memecahkan soal saat game tournament dengan media Roda Putar Akuntansi.

Tabel dan gambar di atas menunjukkan bahwa pada masing-masing siklus terjadi peningkatan Aktivitas Belajar Akuntansi 
siswa. Skor rata-rata Aktivitas Belajar Akuntansi Siswa pada siklus I sebesar 71,09\%. Skor ini didapatkan dari skor Aktivitas Belajar Akuntansi Siswa dari setiap aspek yang terdapat pada indikator yang telah ditentukan. Skor rata-rata pada siklus I tersebut belum mecapai kriteria minimal yang ditentukan sebesar $75 \%$, sehingga tindakan dilanjutkan lagi sampai siklus II agar terjadi peningkatan pada Aktivitas Belajar Akuntansi Siswa. Setelah dilakukan tindakan siklus II, skor rata-rata Aktivitas Belajar Akuntansi Siswa meningkat menjadi sebesar $89,84 \%$. Skor tersebut sudah mencapai kriteria minimal yang ditentukan. Hasil di atas juga memperlihatkan bahwa terjadi peningkatan rata-rata skor Aktivitas Belajar Akuntansi Siswa dari siklus I ke siklus II sebesar $18,75 \%$

\section{SIMPULAN DAN SARAN \\ Simpulan}

Penerapan Model Pembelajaran Kooperatif Tipe Teams Games Tournament (TGT ) Berbantu Media Roda Putar dapat meningkatkan Aktivitas Belajar Akuntansi Siswa Kelas XI Akuntansi 1 SMK Negeri 1 Tempel Tahun Ajaran 2015/2016 yang dibuktikan dengan adanya peningkatan persentase rata-rata Aktivitas Belajar Akuntansi yang diambil melalui observasi dengan lembar observasi. Skor persentase rata-rata aktivitas Belajar Akuntansi telah mencapai indikator keberhasilan Aktivitas Belajar Akuntansi lebih dari $75 \%$ yaitu terjadi peningkatan sebesar $26,37 \%$ (relatif) dan $18,75 \%$ (absolut) dari siklus I sebesar $71,09 \%$ menjadi sebesar $89,84 \%$ pada siklus II. Hasil persentase siklus II menunjukkan bahwa skor tersebut sudah mencapai kriteria minimal yang ditentukan yaitu sebesar $75 \%$.

\section{Saran}

a) Bagi Guru Akuntansi SMK Negeri 1 Tempel:

1) Guru dapat mencoba untuk menerapkan Model Pembelajaran Tipe Teams Games Tournament
(TGT) Berbantu Media Roda Putar yang terbukti bahwa model pembelajaran ini mampu meningkatkan Aktivitas Belajar Akuntansi Siswa.

2) Guru sebaiknya memberikan motivasi lebih kepada siswa untuk bertanya dan aktif dalam menjawab pertanyaan.

b) Bagi Penelitian Selanjutnya:

1) Diharapkan mampu memperbaiki aspek-aspek yang diamati dalam aktivitas belajar sehingga dapat menunjukkan peningkatan Aktivitas Belajar Siswa secara keseluruhan.

2) Diharapkan dapat membuat media roda putar akuntansi berupa software agar menambah jenis media pembelajaran secara modern.

3) Diharapkan dapat menerapkan permainan roda putar akuntansi pada materi pelajaran akuntansi lainnya.

\section{DAFTAR PUSTAKA}

Departemen Pendidikan Nasional. (2003). UU No.20 Tahun 2003 tentang Sistem Pendidikan Nasional. Diambil dari : http://kemenag.go.id/file/ dokumen /UU2003.pdf, pada tanggal 13 Mei 2015

Rochiati Wiraatmadja. (2012). Metode Penelitian Tindakan Kelas. Bandung : PT Remaja Rosdakarya

Sugihartono, dkk. (2012). Psikologi Pendidikan. Yogyakarta: UNY Press

Sardiman A.M. (2011). Interaksi dan Motivasi Belajar Mengajar. Jakarta: Rajawali

Wina Sanjaya. (2014). Strategi Pembelajaran Berorientasi Standar Proses Pendidikan. Jakarta : Kencana Prenada Media

Zainal Arifin dan Adhi Setiyawan. (2012). Pengembangan Pembelajaran Aktif dengan ICT. Yogyakarta : PT Skripta Media Creative 